\title{
Development of hand surgery services in Malaysia
}

\author{
Abdul Hamid Abdul Kadir \\ From 10th Congress of the Asia-Pacific Federation of Societies of Surgery fo the Hand and the 6th Congress \\ of Asia-Pacific Federation of Societies of Hand Therapists \\ Kuala Lumpur, Malaysia. 2-4 October 2014
}

Hand surgery in Malaysia began modestly with the correction of claw deformity in leprosy patients early in the last century, and began to evolve over the years into the treatment of injuries in plantation and industrial workers, at home and then in road crashes.

With training of some of our surgeons in various overseas centres, particularly in the UK and then in USA and Singapore, hand and microsurgery began to be developed in General Hospital Kuala Lumpur and University Malaya Hospital, when they returned home.

An international three-day conference on hand surgery in Kuala Lumpur in the mid-1980's created greater awareness on the topic and helped to bring hand surgery to the fore-front, with setting up hand clinics, training in micro-surgery, and so on, in the major hospitals in Kuala Lumpur initially.

Today, there are dedicated hand surgeons, technicians and hand therapists in the major government and private hospitals throughout the country, providing excellent services in this specialised and demanding area of trauma and reconstructive surgery.

Published: 19 May 2015

Submit your next manuscript to BioMed Central and take full advantage of:

- Convenient online submission

- Thorough peer review

- No space constraints or color figure charges

- Immediate publication on acceptance

- Inclusion in PubMed, CAS, Scopus and Google Scholar

- Research which is freely available for redistribution

\section{() Biomed Central}

